\title{
Bladder reconstruction: The past, present and future (Review)
}

\author{
OMAR M.S. EL-TAJI ${ }^{1}$, ALTAF Q. KHATTAK ${ }^{2}$ and SYED A. HUSSAIN ${ }^{3}$ \\ ${ }^{1}$ Department of Surgical Oncology, Royal Liverpool University Hospital, Liverpool L7 8XP; \\ ${ }^{2}$ Department of Urology, St. Helen's \& Knowsley NHS Teaching Hospitals, University of Liverpool, Prescot L35 5DR; \\ ${ }^{3}$ Department of Molecular and Clinical Cancer Medicine, University of Liverpool, Liverpool L69 3GA, UK
}

Received August 18, 2014; Accepted March 26, 2015

DOI: $10.3892 / \mathrm{ol} .2015 .3161$

\begin{abstract}
Ileal conduit urinary diversion is the gold standard treatment for urinary tract reconstruction following cystectomy. This procedure uses gastrointestinal segments for bladder augmentation, a technique that is often associated with significant complications. The substantial progression in the fields of tissue engineering and regenerative medicine over the previous two decades has resulted in the development of techniques that may lead to the construction of functional de novo urinary bladder substitutes. The present review identifies and discusses the complications associated with current treatment options post-cystectomy. The current techniques, achievements and perspectives of the use of biomaterials and stem cells in the field of urinary bladder reconstruction are also reviewed.
\end{abstract}

\section{Contents}

1. Introduction

2. Biomaterials in bladder regeneration

3. The use of unseeded and cell-seeded matrices in bladder regeneration

4. Stem cells in bladder regeneration

5. Conclusion and perspectives

\section{Introduction}

The past and present. The urinary bladder is an elastic reservoir that is responsible for the low pressure storage of urine. A continent, pain free and healthy bladder is crucial for the preservation of a good quality of life. Numerous conditions

Correspondence to: Mr. Omar M.S. El-Taji, Department of Surgical Oncology, Royal Liverpool University Hospital, Daulby Street, Liverpool L7 8XP, UK

E-mail: omar.eltaji@gmail.com

Key words: urology, bladder, reconstruction, regenerative medicine, tissue engineering disturb the anatomy and physiology of the urinary bladder, leading to insufficient and restricted evacuation of urine (1).

Bladder cancer (BC) is the sixth most common cause of cancer-associated morbidity in the western world: In the UK in 2010, there were 10,300 new cases, and 4,900 cases of BC-associated mortality (2). It represents the most common malignancy of the urinary tract, with a median survival rate following metastasis that rarely surpasses 15 months (3). The vast majority (90\%) of bladder tumours are histologically classified as urothelial cell carcinoma, these tumours are often further classified as being non-muscle invasive BC (NMIBC) or muscle invasive BC (MIBC) (4). On initial presentation, $30 \%$ of patients are diagnosed with an MIBC tumour. From the remainder of patients that had been diagnosed with an NMIBC tumour at presentation, $30 \%$ go on to develop an MIBC during follow-up (5). With the highest susceptibility of recurrence and progression of any malignancy, patients with $\mathrm{BC}$ require consistent surveillance and close follow-up during and, more importantly, following therapy. With such high odds of recurrence, $\mathrm{BC}$ has produced the most expensive management protocol of any malignancy, costing the National Health Service $\sim £ 55.39$ million in the UK per annum (6). The gold standard treatment for organ-confined MIBC is radical cystectomy, with dissection of the pelvic lymph nodes. Regardless, malignancy is not the sole bladder-associated pathology in which cystectomy is indicated (7).

Bladder damage occurs in several additional disorders within the genitourinary (GU) system, including inflammatory conditions (interstitial cystitis/bladder pain syndrome), urinary tract infections, nerve damage (neuropathic bladder) and congenital disorders (spina bifida). In these cases, the essential task is to re-establish the function of the urinary bladder. Medical treatments are limited, and thus, surgical intervention, particularly cystectomy, is often required (8-11).

Since the first BC-associated cystectomy in 1887, the pursuit to identify the most appropriate replacement voiding system has been largely problematic (12). At present, the most common method of bladder replacement or repair involves the use of autologous segments of gastrointestinal tissue, in order to restore bladder storage and voiding capacity (13). This is often achieved through ileal conduit urinary diversion, orthotopic bladder substitution or continent cutaneous diversion (Table I) $(14,15)$.

Since the original application of a free tissue graft in 1917, in which canine bladders were augmented with fascia, various 
Table I. Surgical procedures used post cystectomy.

\begin{tabular}{ll} 
Technique & \multicolumn{1}{c}{ Description } \\
\hline Ileal conduit urinary diversion & $\begin{array}{l}\text { Urine is drained from the ureters to a loop of small bowel anastomosed to the } \\
\text { abdominal skin surface. It is then collected in an external appliance. } \\
\text { This practice imitates the typical role of the urinary bladder through using a } \\
\text { Section of bowel to reconstruct the bladder. } \\
\text { This method uses the ileocaecal valve which may aid the regulation of urination. This } \\
\text { procedure utilises the bowel, which is deployed to mimic the urinary bladder. The } \\
\text { Continent cutaneous diversion }\end{array}$ \\
$\begin{array}{l}\text { Ureters are attached to the pouch. The pouch is then brought to the skin as a stoma. } \\
\text { Possibly the oldest procedure, here the ureters are attached to the large bowel and } \\
\text { urine exits this way. The anal sphincter provides continence. }\end{array}$
\end{tabular}

Table II. Complications of current bladder augmentation procedures through the use of gastrointestinal tissue in the urinary tract.

\begin{tabular}{ll}
\hline Complication & \multicolumn{1}{c}{ Description } \\
\hline Electrolyte disturbances & $\begin{array}{l}\text { Hyperchloreamic, hypokalaemic metabolic acidosis is the most common complication. A number } \\
\text { of these patients will be required to take life long oral Sodium bicarbonate as a result. } \\
\text { Loss of segments of bowel or stomach can impair vitamin B12/ bile salt/fat/fat soluble vitamin } \\
\text { absorption. Vitamin B12 deficiency can manifest as peripheral neuropathy. }\end{array}$ \\
Drugs can be reabsorbed by the intestinal segments that have been incorporated into the urinary \\
tract, causing toxicity. Methotrexate, phenytoin and lithium in particular result in therapeutic \\
changes. Dose adaptation and close surveillance is often required.
\end{tabular}

additional materials have been utilized as free grafts (16). The ileum, however, is the most frequently utilized segment in bladder augmentation, due to its notably simple mobilization, extensive mesentery and copiousness; features that are particularly appropriate for urinary tract substitution (17). Although the use of gastrointestinal segments in bladder reconstruction was first proposed almost 150 years ago, it remains the gold standard due to the absence of a superior alternative. This was demonstrated by Stein et al (18), who observed excellent long-term survival rates in patients undergoing radical cystectomy. Whilst radical extirpation of the bladder is frequently successful, from an oncological perspective, substantial morbidity is associated with enteric interposition within the GU tract (Table II) (19-22). Surgical intervention itself requires procedures on the urinary and gastrointestinal tracts which are associated with complication rates of $\leq 66 \%$. Considering that the vast majority of patients that require cystectomy and consequent bladder substitution are elderly and suffer from other co-morbidities, in particular renal impairment, urologists find themselves fighting an uphill battle in surgical management post-cystectomy (16).

Certain bladder pathologies, in particular metastatic BC, are managed medically prior to considering radical cystectomy. This method of organ preservation involves aggressive treatment through surgery and radiotherapy, often with neo-adjuvant chemotherapy as the treatment of choice (23). Currently, only multidrug platinum-based chemotherapeutic regimens have been successful $(24,25)$, whereas monotherapy treatments have failed $(26,27)$. The methotrexate, vinblastine, adriamycin and cisplatin (MVAC) and gemcitabine and cisplatin (gem-cis) regimens have been the most commonly used chemotherapeutic treatment regimens. However, the clinical efficacy of cisplatin-based therapy in BC is currently restricted by the rapid development of drug resistance in the majority of patients, frequently leading to therapeutic failure (28). This was demonstrated in a previous study in which response rates from BC patients receiving chemotherapeutic drug intervention in phase II trials varied between 20 and $60 \%$, with the 


\section{ORGANS}

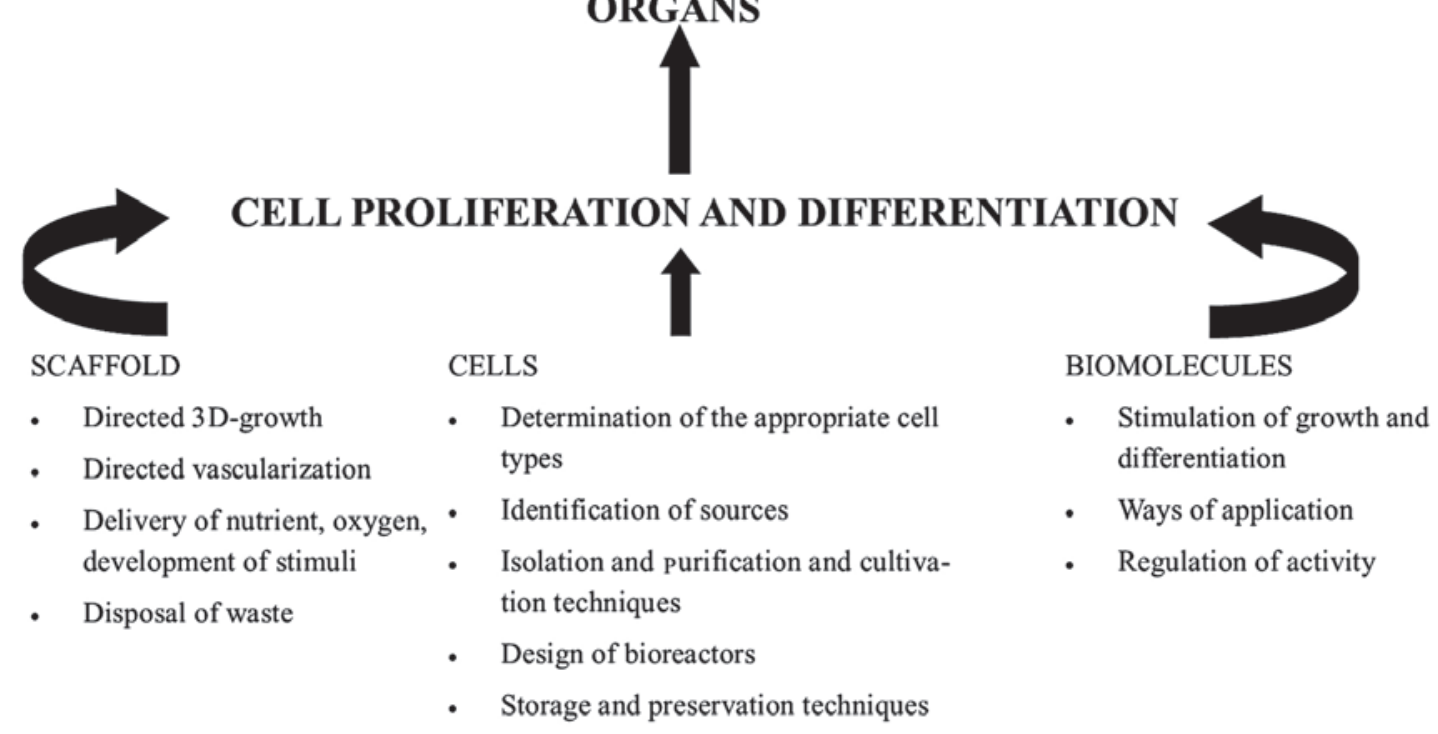

Figure 1. Constituents of tissue engineering. The idea of bladder reconstruction is to design and ultimately construct the perfect artificial bladder. This is achieved through identifying vital pathways for tissue regeneration and encouraging these pathways by providing suitable progenitor cells, a scaffold of suitable quality to direct growth, an adequate blood supply and adequate cell signalling regulation.

majority of survival rate advantage in the randomised control trial setting $(29,30)$. This has resulted in the ever apparent requirement for bladder reconstruction.

The future. The absence of autologous tissue with parallel properties to the native bladder has directed numerous studies to develop alternative methods of bladder substitution, avoiding the use of bowel tissue altogether. The theory of substituting the native bladder with a synthetic prosthesis has always been an attractive prospect in the development of cutting edge technology. Thus, tissue engineering, cell and stem cell biology, material science and regenerative medicine are at the forefront of medical research (31).

The fields of tissue engineering and regenerative medicine have witnessed substantial progression over the previous two decades. Various studies have investigated the possibility of regenerating multilayer urothelium, which led to the first clinical trial in 2006, in which Atala et al (32) investigated tissue engineered bladders created from cell seeded grafts. The potential of such novel findings has underlined the requirement for further advances in tissue engineering and material science in order to define the properties required for the ultimate reconstructive material and method of implantation.

Tissue engineering is the mainstay of regenerative medicine. It employs the disciplines of cell biology, transplantation, material science and biomedical engineering, towards identifying alternatives that can re-establish and preserve the regular function of damaged tissues and organs (Fig. 1) (33). Although the human body is outstanding in its ability to repair damaged tissue, these reparative processes are frequently restricted to the development of scar tissue. This often proves detrimental in the function of the bladder (34). The ideal artificial bladder should possess properties similar to that of the native urinary bladder. It should possess the ability to store urine at low pressure in a watertight structure, similar to a mechanical reservoir, and permit voluntary voiding with minimal reflux.
This structure should also be constructed from inert material and cause minimal complications in the patient so that long-term renal function is not compromised (35). Previously published animal studies have demonstrated promising results in the field of regenerative medicine, and it represents a possible solution for the treatment of a number of urological conditions in the future (31).

Tissue engineering strategies vary, and currently, studies are being orientated in two directions: Firstly, to identify the most appropriate type of stem cell for regeneration and to proficiently incorporate it into bladder cells; secondly, to determine the most appropriate material and technique of embedding these cells using tissue engineered grafts (Fig. 2) (36,37). The selected grafts must exhibit all the qualities of the native tissue, acting ultimately as microenvironments for the implanted cells to prosper (38).

\section{Biomaterials in bladder regeneration}

There are distinct benefits to using biocompatible material in regenerative medicine for the purpose of cell delivery vehicles, and for bearing the physical maintenance required for tissue replacement (39). Scaffolds are constructs that are designed to direct tissue development and the growth of cells during the process of healing (40). Bladder replacements should therefore provide provisional mechanical support, adequate to endure forces exerted from neighbouring structures, whilst maintaining a potential zone for tissue development. Biomaterials used for bladder replacements should possess the ability to be easily manipulated into a hollow, spherical configuration. Furthermore, the biomaterials should possess the ability to biodegrade for complete tissue development, without causing inflammation. Autologous tissue has been experimented on for bladder repair since the early 1980s (41). The use of omentum, pericardium, stomach and skin has been attempted with limited success (42-45). It was the lack of watertight properties 


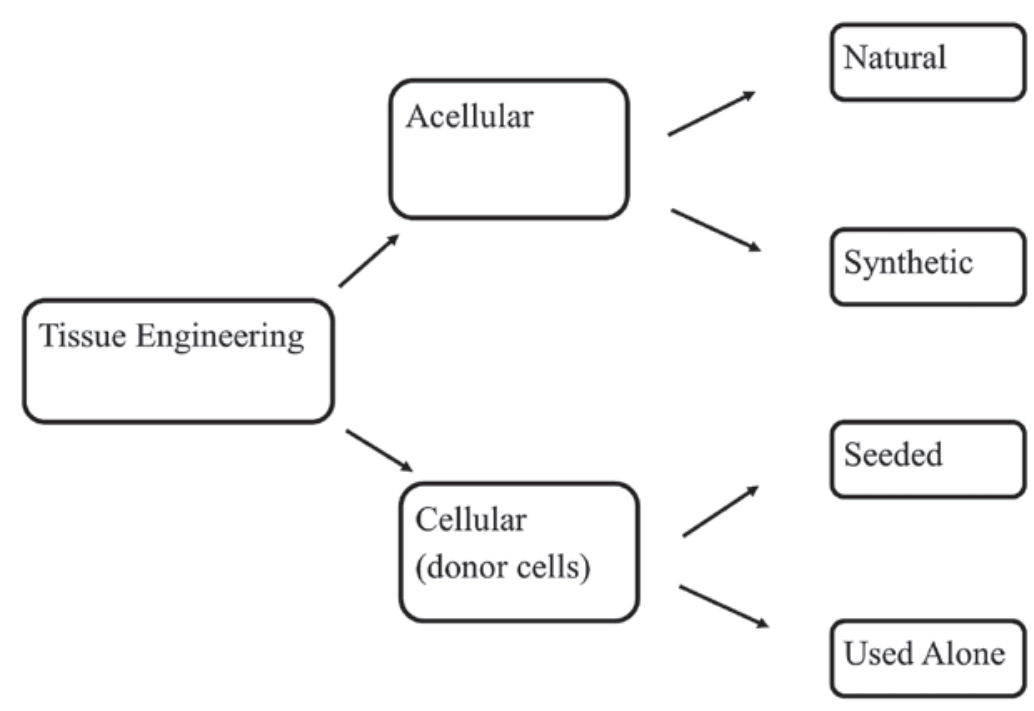

Figure 2. Tissue engineering strategies. Tissue engineering approaches can be acellular or cellular. The acellular strategy uses natural or synthetic scaffolds that aim to improve the body's own capability at repairing itself and differentiating into new tissue. The cellular strategy uses donor cells that can be seeded by incorporation into the scaffold or used alone (stem cell approach). At present, the cell seeded approach has demonstrated superiority in the formation of a tissue engineered bladder.

that led to the failure of these materials. It is clear that the anatomical and physiological properties of the urinary bladder are not easily substituted.

Biomaterials can be divided into 3 main categories: i) Naturally derived matrices, including collagen; ii) acellular tissue matrices, including bladder submucosa; and iii) synthetic matrices, including poly lactic-co-glycolic acid (PLGA) (46).

Naturally derived matrices. Collagen is considered to be the most ubiquitous protein in the human body, and it is often used alongside alginate as a natural matrix. It is useful in tissue engineering, as it possesses the ability to be easily manipulated and does not provoke an immune response (47). Through the use of innovative inkjet technology, it has been possible to use bio-printing to create a naturally derived 3D construct, with a precise arrangement of growth factors and other cellular components, into a patient-specific scaffold (48).

Acellular tissue matrices. Decellularised matrices are the most commonly used naturally derived urological matrices. They are usually harvested from autologous, allogenic or xenogenic tissue $(49,50)$. Chemical or mechanical processing decellularises the matrix, removing all cellular components and leaving a natural platform for tissue development (51). The most common origin of decellularised matrices is tissue harvested from the bladder or small intestinal mucosa (52). Once implanted, the matrices eventually degrade and are ultimately replaced by an extracellular matrix. The matrices provide cells with a structural support that can dictate the tissue structure. Bladder acellular matrix may be the most extensively used scaffold in tissue engineering. It has been demonstrated that the cells have the ability to induce the ingrowth of urothelium, smooth muscle, endothelium and nerve cells (53). Perhaps the greatest advantage of the use of acellular matrices is the ability to provide a method of neovascularisation following graft insertion, promoting graft survival. Kikuno et al (54) demonstrated that nerve growth factor and vascular endothelial growth factor enhanced bladder acellular matrix grafting in neurogenic rat bladders through increased angiogenesis and neurogenesis (55).

However, in general, these materials possess various drawbacks depending on their graft origin. Autologous materials have proven difficult to reproduce as a result of increased patient morbidity associated with the graft harvest (56). The increased cost in allograft and xenograft material production, in addition to the risk of disease transmission and varied mechanical strength, is crucial in their limited clinical application $(56,57)$. Furthermore, the use of natural decellularised matrices requires tissue that exhibits no principal pathological change, and is therefore unfeasible in certain patients $(58,59)$. In addition, the aggressive decellularisation and sterilisation protocols used can denature proteins in the extracellular matrix, damaging the physiological environment (60).

Synthetic matrices. The use of synthetic material in patients in which the native bladder has undergone pathological change, such as BC, is hypothesised to be the ideal solution. The most commonly used materials in experimental studies and clinical trials are Teflon, silicon and collagen matrices (61). However, cell and tissue incompatibilities appear to be the major restrictions of these materials, leading to the development of other synthetic polymers, such as PLGA (62-65). These materials were designed specifically to possess adequate structural and biological properties, which can be manipulated for optimal cell proliferation and differentiation (66). In addition, these scaffolds are safe, possess controlled properties of degradation rate and strength, are readily available and possess the ability to carry vital growth factors, such as vascular endothelial growth factor, for neovascularisation (67-69). Indeed, the most attractive property of PLGA compared with older polymers, such as Teflon, is its resorbable biodegradability. This eliminates the disadvantages of infection, calcification and unfavourable connective tissue responses observed in older polymers (70). When using polymers, tissue recognition is difficult, and often 
requires immunosuppressive therapy. However, it has now been demonstrated that novel biological factors, including adhesive proteins such as collagen and fibronectin and growth factors such as basic fibroblast growth factor, epidermal growth factor and insulin, are able to enhance cell recognition $(71,72)$.

The failure of certain materials in clinical cases has been extensively reported, including plastic moulds $(73,74)$, gelatin sponges $(75,76)$, Japanese paper produced from the rice paper plant (Tetrapanax papyrifer) $(77,78)$ and bovine pericar$\operatorname{dium}(79,80)$.

Nanotechnology, which arose in the last decade of the 20 th century, has been used in the formation of matrices that can be composed of natural and synthetic materials. The use of nanotechnology permits the development of a graft that can be manipulated to produce characteristics with definitive properties in order to promote optimal cell proliferation and tissue differentiation (53). A previous study investigated the effect of surface roughness on the interaction with matrix proteins (81). Vitronectin absorbance improved by $20 \%$ with the addition of nanotechnology-induced surface roughness in the synthetic materials compared with the nanosmooth surface. Similarly, enhanced adhesion and proliferation of urothelial cells has been demonstrated with increased synthetic surface roughness (82).

\section{The use of unseeded and cell-seeded matrices in bladder regeneration}

Although there have been studies illustrating the use of unseeded matrices in bladder tissue engineering, the results of these studies have been inconclusive. The normal regeneration of the urothelium layer has been demonstrated in unseeded grafts used for cystoplasty, however, the muscular layer did not develop (83). By contrast, the cell-seeded approach has produced more positive and consistent results in bladder reconstruction, and has been the most extensively investigated strategy in reconstruction. This approach involves seeding of a scaffold with autologous patient-derived cells, which is then transplanted back into the patient to accomplish regeneration (32).

In a study conducted on beagle dogs following subtotal cystectomy, polyglycolic acid acellular matrices were seeded with urothelium and smooth muscle cells. These dogs demonstrated a $95 \%$ increase in pre-operative bladder capacity compared with dogs treated with an unseeded matrix, indicating a $46 \%$ increase in pre-operative bladder capacity (84).

The study by Atala et al (32) was crucial for the first laboratory-created organ to be transplanted into the human body. The authors demonstrated an increase in bladder compliance and capacity, and a reduction in end filling pressure in 7 patients with neurogenic bladder (myelomeningocele). These patients underwent cystoplasty created from autologous cells seeded on collagen-polyglycolic acid scaffolds. This small clinical study established the possibility of using tissue-engineered substitutes for organ replacements in humans, circumventing the complications of intestinal substitutes (32).

\section{Stem cells in bladder regeneration}

Historically, tissue engineering has depended on autologous cells from the host organ. However, physiologically normal tissue may not always be available for harvest to elaborate a regenerative cystoplasty, this has led to the use of stem cells as an alternative to restore urinary bladder function. The aim of using stem cells as a therapeutic option is to achieve adequate differentiation into urothelial cells and smooth muscle cells, so that the normal histological structure is maintained for use as a potential resource for cell-based therapy in urology (85).

Embryonic stem cells are a group of pluripotent stem cells and exhibit two valuable attributes, including the capability to undergo self-renewal and the capability to differentiate into numerous specialised cell types. The in vivo benefits of these have been demonstrated previously $(86,87)$, although the exact culture conditions which would enable controlled differentiation are yet to be identified. However, their potential for tumorigenicity, the prospect of immune rejection and the ethical dilemmas associated with embryonic stem cells have limited their clinical application (85).

Adult stem cells are the most extensively investigated cell types in stem cell biology, regardless, progression has been slow. Despite this, study of adult stem cells is ongoing due to their extensive potential to be applied as therapies in a vast array of disorders. The most promising source of adult stem cells is adult bone marrow. The use of autologous adult stem cells avoids the obstacles associated with an immune response $(88,89)$, which is useful for autologous and tissue-specific regenerative therapies. Within the past two decades, stem cells have been identified throughout the tissues of the body, not just the bone marrow (90). It has been indicated that stem cells may function as primary repair entities for the particular organ in which they reside. These tissue-specific progenitors are now the subject of numerous different areas of research (88).

Mesenchymal stem cells (MSCs) are derived from the bone marrow stroma. MSCs have been demonstrated to differentiate in vitro into a variety of tissue types, including smooth muscle, urothelium and endothelial cells. It is for this reason that bone marrow-derived MSCs are an attractive candidate for bladder tissue regeneration (91). Chung et al (92) reported positive results in healthy rat bladders following the introduction of porcine small intestinal submucosa seeded with MSCs from rat bone marrow. These rats exhibited normal urinary bladder architecture, and histological analysis demonstrated well-differentiated urothelial and smooth muscle cells compared with control experiments using unseeded intestinal submucosa (92).

Amniotic fluid-derived stem (AFS) cells, adipose-derived stem cells, and stem cells isolated from hair have all demonstrated the capability of differentiating into different urinary bladder cells in vitro $(52,93,94)$. AFS cells were initially isolated for therapeutic use in 2007 and represent a minor subset of cells originating from the placenta and amniotic fluid (95). AFS cells have been demonstrated to expand extensively, doubling every $36 \mathrm{~h}$ (96). They have the advantage over embryonic stem cells in that they do not form tumours in vivo (95). AFS cells possess a differentiation potential between that of adult stem cells and embryonic stem cells and can be obtained from routine clinical amniocentesis, prenatal chorionic villus biopsies and placental biopsies performed after birth (95). Since their identification, these cells have been demonstrated to differentiate into functioning cell types of numerous different organs and to prevent bladder hypertrophy in cryo-injured mouse bladders in vitro via the regulation of post-injury bladder remodelling (97). AFS cells possess a wide range of potential applications in the field 
of regenerative medicine, and may in theory supply the vast majority of the UK with suitable genetic matches for transplantation (98-100).

Stem cells are currently employed in tissue engineering using two main methods, including implantation of the stem cells in vivo without pre-differentiation and induction of stem cell differentiation towards the bladder in vitro followed by its implantation in vivo (101). The first method is often employed when a section of the bladder requires reconstruction, in comparison with the second method that is used when de novo whole bladder reconstruction is required.

Innervation is vital in bladder reconstruction. The autonomic nervous system controls the function of the bladder, thus a poorly functioning neuronal network can lead to significant bladder dysfunction (102). It has been indicated that seeding Schwann cells and neurotrophic factors may encourage nerve innervation of the urinary bladder (103).

Several bladder malformations exist, which are often identified prenatally with sonography. The future prenatal management of patients with bladder disease has emerged as a notable possibility (104). The potential to have readily available urological tissue at birth for a one-stage reconstruction following prenatal ultrasound-guided bladder biopsy is of note as this would present a significant advancement for the treatment of congential urinary tract abnormalities as cells could be harvested and grown in transplantable tissue during gestation. This has been successfully demonstrated in foetal lambs (105). Chondrocytes obtained from hyaline and elastic cartilage were harvested from fetal lambs, expanded in vitro and seeded onto biodegradable scaffolds. The scaffolds were then implanted as replacement tracheal tissue in fetal lambs. Strucural support and patency of the tissue engineered cartilage was maintained and all lambs that were allowed to reach term were able to breathe spontaneously. Thus, this may be useful for in utero repair of congenital tracheal abnormalities, such as tracheal atresia and agenesis $(106,107)$.

\section{Conclusion and perspectives}

Existing data indicates a forthcoming role of tissue engineering disciplines in the management of urological diseases. With the extensive advancements within the field in previous years, the future of urology appears positive. However, the current knowledge of bladder reconstruction is insufficient in order to use it as a clinical standard in mainstream urological practice. Additional in vitro studies are required to make this possible. The most significant obstacle in material science is the equilibrium between the creation of biomaterials that are patient- and disease-specific and fit for purpose and a cost-effective manufacturing process. The primary objective in the field of cell biology and transplantation is not solely to control stem cell differentiation in vivo but also to be able to manage their growth following transplantation. The most significant aspect of cell type selection is the degree of regenerative potential; the more regenerative the cell is, the more likely it is to survive when implanted in vivo. The survival of artificial tissue following transplantation has been a significant obstacle thus far in current tissue engineering strategies. Other factors other than cell type selection are also important, however these factors often depend on the ability for the tissue to maintain initial growth and survive. Thus, as the tissue grows a healthy self-sustained process of self repair is required, however, this will vary depending on the cell type used.

\section{References}

1. Walters MD and Weber AM: Anatomy of the lower urinary tract, rectum and pelvic floor. In: Urogynecology and Pelvic Reconstructive Surgery. Walters MD and Karram MM (eds). 2nd edition. Mosby, St. Louis, MO, pp3-13, 2000.

2. Cancer Research UK: Bladder Cancer Survival Statistics. www. cancerresearchuk.org/cancer-info/cancerstats/?=5441. Accessed April 10, 2015.

3. BMJ: Best practise: Epidemiology. http://bestpractice.bmj. com/best-practice/monograph/980/basics/epidemiology.html. Accessed April 11, 2015.

4. Cancer Research UK: Types of bladder cancer. http://cancerhelp.cancerresearchuk.org/type/bladder-cancer/ about/types-of-bladder-cancer\#spread. Accessed April 11, 2015.

5. Witjes JA, Compérat E, Cowan NC, et al: EAU guidelines on muscle-invasive and metastatic bladder cancer: Summary of the 2013 guidelines. Eur Urol 65: 778-792, 2014.

6. Sievert KD, Amend B, Nagele U, Schilling D, Bedke J, Horstmann M, Hennenlotter J, Kruck S and Stenzl A: Economic aspects of bladder cancer: What are the benefits and costs? World J Urol 27: 295-300, 2009.

7. Lee RK, Abol-Enein H, Artibani W, et al: Urinary diversion after radical cystectomy for bladder cancer: Options, patient selection, and outcomes. BJU Int 113: 11-23, 2014.

8. Hautmann S, Felix-Chun KH, Currlin E, et al: Cystectomy for indications other than bladder cancer. Urologe A 43: 172-177, 2004 (In German).

9. Evans B, Montie JE and Gilbert SM: Incontinent or continent urinary diversion: How to make the right choice. Curr Opin Urol 20: 421-425, 2010.

10. Westney OL: The neurogenic bladder and incontinent urinary diversion. Urol Clin North Am 37: 581-592, 2010.

11. Andersen AV, Granlund P, Schultz A, Talseth T, Hedlund H and Frich L: Long-term experience with surgical treatment of selected patients with bladder pain syndrome/interstitial cystitis. Scand J Urol Nephrol 46: 284-289, 2012.

12. Poole-Wilson DS and Barnard RJ: Total cystectomy for bladder tumours. Br J Urol 43: 16-24, 1971.

13. Cody JD, Nabi G, Dublin N, McClinton S, Neal DE, Pickard R and Yong SM: Urinary diversion and bladder reconstruction/replacement using intestinal segments for intractable incontinence or following cystectomy. Cochrane Database Syst Rev 15: CD003306, 2012.

14. Parekh DJ and Donat SM: Urinary diversion: Options, patient selection, and outcomes. Semin Oncol 34: 98-109, 2007.

15. Basic DT, Hadzi-Djokic J and Ignjatovic I: The history of urinary diversion. Acta Chir Iugosl 54: 9-17, 2007.

16. Neuhof H: Facial transplantation into visceral defects: An experimental and clinical study. Surg Gynecol Obstet 25: 383, 1917.

17. Moon A, Vasdev N and Thorpe AC: Continent urinary diversion. Indian J Urol 29: 303-309, 2013.

18. Stein JP, Lieskovsky G, Cote R, et al: Radical cystectomy in the treatment of invasive bladder cancer: Long-term results in 1,054 patients. J Clin Oncol 19: 666-675, 2001.

19. Mills RD and Studer UE: Metabolic consequences of continent urinary diversion. J Urol 161: 1057-1066, 1999.

20. Shimko MS, Tollefson MK, Umbreit EC, Farmer SA, Blute ML and Frank I: Long-term complications of conduit urinary diversion. J Urol 185: 562-567, 2011.

21. Hautmann RE: Urinary diversion: Ileal conduit to neobladder. J Urol 169: 834-842, 2003.

22. Hyndman ME, Kaye D, Field NC, et al: The use of regenerative medicine in the management of invasive bladder cancer. Adv Urol 2012: 653652, 2012.

23. Hussain SA, Moffitt DD, Glaholm JG, Peake D, Wallace DM and James ND: A phase I-II study of synchronous chemoradiotherapy for poor prognosis locally advanced bladder cancer. Ann Oncol 12: 929-935, 2001.

24. Harker WG, Meyers FJ, Freiha FS, Palmer JM, Shortliffe LD, Hannigan JF, McWhirter KM and Torti FM: Cisplatin, methotrexate, and vinblastine (CMV): An effective chemotherapy regimen for metastatic transitional cell carcinoma of the urinary tract. A Northern California Oncology Group study. J Clin Oncol 3: 1463-1470, 1985. 
25. Sternberg CN, Yagoda A, Scher HI, et al: Preliminary results of M-VAC (methotrexate, vinblastine, doxorubicin and cisplatin) for transitional cell carcinoma of the urothelium. J Urol 133: 403-407, 1985.

26. Saxman SB, Propert KJ, Einhorn LH, Crawford ED, Tannock I, Raghavan D, Loehrer PJ Sr and Trump D: Long-term follow up of a phase III intergroup study of cisplatin alone or in combination with methotrexate, vinblastine, and doxorubicin in patients with metastatic urothelial carcinoma: A cooperative group study. J Clin Oncol 15: 2564-2569, 1997.

27. Waxman J and Barton C: Carboplatin-based chemotherapy for bladder cancer. Cancer Treat Rev 19 (Suppl C): S21-S25, 1993.

28. Stewart DJ: Mechanisms of resistance to cisplatin and carboplatin. Crit Rev Oncol Hematol 63: 12-31, 2007.

29. Hussain SA, Stocken DD, Riley P, et al: A phase I/II study of gemcitabine and fractionated cisplatin in an outpatient setting using a 21-day schedule in patients with advanced and metastatic bladder cancer. Br J Cancer 91: 844-849, 2004.

30. James ND, Hussain SA, Hall E, et al; BC2001 Investigators: Radiotherapy with or without chemotherapy in muscle-invasive bladder cancer. N Engl J Med 366: 1477-1488, 2012.

31. Atala A: Tissue engineering for bladder substitution. World J Urol 18: 364-370, 2000.

32. Atala A, Bauer SB, Soker S, Yoo JJ and Retik AB Tissue-engineered autologous bladders for patients needing cystoplasty. Lancet 367: 1241-1246, 2006.

33. Aboushwareb T, McKenzie P, Wezel F, Southgate J and Badlani G: Is tissue engineering and biomaterials the future for lower urinary tract dysfunction (LUTD)/pelvic organ prolapse (POP)? Neurourol Urodyn 30: 775-782, 2011.

34. Baskin LS, Sutherland RS, Thomson AA, Nguyen HT, Morgan DM, Hayward SW, Hom YK, DiSandro M and Cunha GR: Growth factors in bladder wound healing. J Urol 157: 2388-2395, 1997.

35. Korossis S, Bolland F, Ingham E, Fisher J, Kearney J and Southgate J: Review: Tissue engineering of the urinary bladder: considering structure-function relationships and the role of mechanotransduction. Tissue Eng 12: 635-644, 2006.

36. Petrovic V, Stankovic J and Stefanovic V: Tissue engineering of the urinary bladder: Current concepts and future perspectives. ScientificWorld Journal 11: 1479-1488, 2011.

37. Shokeir AA, Harraz AM and El-Din AB: Tissue engineering and stem cells: Basic principles and applications in urology. Int J Urol 17: 964-973, 2010

38. Wood D and Southgate J: Current status of tissue engineering in urology. Curr Opin Urol 18: 564-569, 2008.

39. Furth ME, Atala A and Van Dyke ME: Smart biomaterials design for tissue engineering and regenerative medicine. Biomaterials 28: 5068-5073, 2007.

40. Chan BP and Leong KW: Scaffolding in tissue engineering: General approaches and tissue-specific considerations. Eur Spine J 17 (Suppl 4): S467-S479, 2008.

41. Davis NF, Callanan A, McGuire BB, Mooney R, Flood HD and McGloughlin TM: Porcine extracellular matrix scaffolds in reconstructive urology: An ex vivo comparative study of their biomechanical properties. J Mech Behav Biomed Mater 4 375-382, 2011

42. Goldstein MB, Dearden LC and Gualtieri V: Regeneration of subtotally cystectomized bladder patched with omentum: An experimental study in rabbits. J Urol 97: 664-668, 1967.

43. Andretto R, Gonzales J, Guidugli Netro J, de Miranda JF and Antunes AM: Experimental cystoplasty in dogs using preserved equine pericardium. AMB Rev Assoc Med Bras 27: 153-154, 1981 (In Portuguese).

44. Nguyen DH and Mitchell ME: Gastric bladder reconstruction. Urol Clin North Am 18: 649-657, 1991.

45. Draper JW and Stark RB: End results in the replacement of mucous membrane of the urinary bladder with thick-split grafts of skin. Surgery 39: 434-440, 1956.

46. Atala A: Tissue engineering of human bladder. Br Med Bull 97: 81-104, 2011.

47. Dahms SE, Piechota HJ, Dahiya R, Lue TF and Tanagho EA Composition and biomechanical properties of the bladder acellular matrix graft: Comparative analysis in rat, pig and human. Br J Urol 82: 411-419, 1998.

48. Mahfouz W, Elsalmy S, Corcos J and Fayed AS: Fundamentals of bladder tissue engineering. Afr J Urol 19: 51-57, 2013.

49. Yoo JJ, Meng J, Oberpenning F and Atala A: Bladder augmentation using allogenic bladder submucosa seeded with cells. Urology 51: 221-225, 1998 .
50. Sutherland RS, Baskin LS, Hayward SW and Cunha GR Regeneration of bladder urothelium, smooth muscle, blood vessels and nerves into an acellular tissue matrix. J Urol 156: 571-577, 1996

51. Crapo PM, Gilbert TW and Badylak SF: An overview of tissue and whole organ decellularization processes. Biomaterials 32 : 3233-3243, 2011

52. Langer R and Vacanti JP: Tissue engineering. Science 260: 920-926, 1993

53. Brehmer B, Rohrmann D, Becker C, Rau G and Jakse G Different types of scaffolds for reconstruction of the urinary tract by tissue engineering. Urol Int 78: 23-29, 2007.

54. Kikuno N, Kawamoto K, Hirata H, et al: Nerve growth factor combined with vascular endothelial growth factor enhances regeneration of bladder acellular matrix graft in spinal cord injury-induced neurogenic rat bladder. BJU Int 103: 14241428,2009

55. Atala A: Recent developments in tissue engineering and regenerative medicine. Curr Opin Pediatr 18: 167-171, 2006

56. Orabi H, Bouhout S, Morissette A, Rousseau A, Chabaud S and Bolduc S: Tissue engineering of urinary bladder and urethra: Advances from bench to patients. ScientificWorldJournal 2013: 154564,2013

57. Brown AL, Farhat W, Merguerian PA, Wilson GJ, Khoury AE and Woodhouse KA: 22 week assessment of bladder acellular matrix as a bladder augmentation material in a porcine model. Biomaterials 23: 2179-2190, 2002.

58. Subramaniam R, Hinley J, Stahlschmidt J and Southgate J: Tissue engineering potential of urothelial cells from diseased bladders. J Urol 186: 2014-2020, 2011.

59. Chung SY: Bladder tissue-engineering: a new practical solution? Lancet 367: 1215-1216, 2006.

60. Atala A: Autologous cell transplantation for urologic reconstruction. J Urol 159: 2-3, 1998

61. Matoka DJ and Cheng EY: Tissue engineering in urology. Can Urol Assoc J 3: 403-408, 2009.

62. Bogash M, Kohler FP, Scott RH and Murphy JJ: Replacement of the urinary bladder by a plastic reservoir with mechanical valves. Surg Forum 10: 900-903, 1960.

63. Bona AV and De Gresti A: Partial substitution of the bladder wall with teflon tissue. (Preliminary and experimental note on the impermeability and tolerance of the prosthesis). Minerva Urol 18: 43-47, 1966 (In Italian).

64. Kelâmi A, Dustmann HO, Lüdtke-Handjery A, Cárcamo V and Herlld G: Experimental investigations of bladder regeneration using teflon-felt as a bladder wall substitute. J Urol 104 693-698, 1970.

65. Rohrmann D, Albrecht D, Hannappel J, Gerlach R, Schwarzkopp, G, and Lutzeyer W: Alloplastic replacement of the urinary bladder. J Urol 156: 2094-2097, 1996.

66. Baker SC, Rohman G, Southgate J and Cameron NR: The relationship between the mechanical properties and cell behaviour on PLGA and PCL scaffolds for bladder tissue engineering. Biomaterials 30: 1321-1328, 2009.

67. Pattison MA, Wurster S, Webster TJ and Haberstroh KM Three dimensional, nano-structured PLGA scaffolds for bladder tissue replacement applications. Biomaterials 26: 2491-2500, 2005.

68. Pariente JL, Kim BS and Atala A: In vitro biocompatibility assessment of naturally derived and synthetic biomaterials using normal human urothelial cells. J Biomed Mater Res 55: 33-39, 2001.

69. Chen FM, Zhang M and Wu ZF: Toward delivery of multiple growth factors in tissue engineering. Biomaterials 31: 6279-6308, 2010 .

70. Ulery BD, Nair LS and Laurencin CT: Biomedical applications of biodegradable polymers. J Polym Sci B Polym Phys 49: 832-864, 2011

71. Harrington DA, Sharma AK, Erickson BA and Cheng EY: Bladder tissue engineering through nanotechnology. World J Urol 26: 315-322, 2008.

72. Elbert DL and Hubbell JA (eds): Surface treatments of polymers for biocompatibility. In: Annual Review of Materials Science. Vol 26. Annual Reviews, Palo Alto, CA, pp365-394, 1996.

73. Bohne AW and Urwiller KL: Experience with urinary bladder regeneration. J Urol 77: 725-732, 1957.

74. Portilla Sanchez R, Blanco FL, Santamarina A, Casals Roa J, Mata $J$ and Kaufman A: Vesical regeneration in the human after total cystectomy and implantation of a plastic mould. $\mathrm{Br}$ J Urol 30: 180-188, 1958 
75.Tsuji I, Kuroda K, Fujieda J, Shiraishi Y and Kunishima K Clinical experiences of bladder reconstruction using preserved bladder and gelatin sponge bladder in the case of bladder cancer. J Urol 98: 91-92, 1967.

76. Orikasa S and Tsuji I: Enlargement of contracted bladder by use of gelatin sponge bladder. J Urol 104: 107-110, 1970.

77. Taguchi H, Ishizuka E and Saito K: Cystoplasty by regeneration of the bladder. J Urol 118: 752-756, 1977.

78. Fujita K: The use of resin-sprayed thin paper for urinary bladder regeneration. Invest Urol 15: 355-357, 1978.

79. Moon SJ, Kim DH, Jo JK, et al: Bladder reconstruction using bovine pericardium in a case of enterovesical fistula. Korean J Urol 52: 150-153, 2011.

80. Pokrywczynska M, Adamowicz J, Sharma AK and Drewa T: Human urinary bladder regeneration through tissue engineering - an analysis of 131 clinical cases. Exp Biol Med (Maywood) 239: 264-271, 2014.

81. Shakhssalim N, Dehghan MM, Moghadasali R, Soltani MH, Shabani I and Soleimani M: Bladder tissue engineering using biocompatible nanofibrous electrospun constructs: Feasibility and safety investigation. Urol J 9: 410-419, 2012.

82. Chun YW, Khang D, Haberstroh KM and Webster TJ: The role of polymer nanosurface roughness and submicron pores for improving bladder urothelial cell density and inhibiting calcium oxalate stone formation. Nanotechnology 20: 085104, 2009.

83. Probst M, Dahiya R, Carrier S and Tanagho EA: Reproduction of functional smooth muscle tissue and partial bladder replacement. Br J Urol 79: 505-515, 1997.

84. Oberpenning F, Meng J, Yoo JJ and Atala A: De novo reconstitution of a functional mammalian urinary bladder by tissue engineering. Nat Biotechnol 17: 149-155, 1999.

85. Aboushwareb T and Atala A: Stem cells in urology. Nat Clin Pract Urol 5: 621-631, 2008

86. Lamba DA, Gust J and Reh TA: Transplantation of human embryonic stem cell derived photoreceptors restores some visual function in Crx-deficient mice. Cell Stem Cell 4: 73-79, 2009.

87. Yang D, Zhang ZJ, Oldenburg M, Ayala M and Zhang SC: Human embryonic stem cell-derived dopaminergic neurons reverse functional deficit in parkinsonian rats. Stem Cells 26: 55-63, 2008.

88. Ballas CB, Zielske SP and Gerson SL: Adult bone marrow stem cells for cell and gene therapies: Implications for greater use. J Cell Biochem Suppl 38 (S38): 20-28, 2002.

89. Gonzalez MA and Bernad A: Characteristics of adult stem cells. Adv Exp Med Biol 741: 103-120, 2012.

90. Spradling A, Drummond-Barbosa D and Kai T: Stem cells find their niche. Nature 414: 98-104, 2001.

91. da Silva Meirelles L, Chagastelles PC and Nardi NB: Mesenchymal stem cells reside in virtually all post-natal organs and tissues. J Cell Sci 119: 2204-2213, 2006.

92. Chung SY, Krivorov NP, Rausei V, et al: Bladder reconstitution with bone marrow derived stem cells seeded on small intestinal submucosa improves morphological and molecular composition. J Urol 174: 353-359, 2005.
93.Zuk PA, Zhu M, Ashjian P, et al: Human adipose tissue is a source of multipotent stem cells. Mol Biol Cell 13: 4279-4295, 2002.

94.Drewa T: Using hair-follicle stem cells for urinary bladder-wall regeneration. Regen Med 3: 939-944, 2008.

95.De Coppi P, Bartsch G Jr, Siddiqui MM, et al: Isolation of amniotic stem cell lines with potential for therapy. Nat Biotechnol 25: 100-106, 2007.

96. Mosquera A, Fernández JL, Campos A, Goyanes VJ, Ramiro-Díaz J and Gosálvez J: Simultaneous decrease of telomere length and telomerase activity with ageing of human amniotic fliuds cells. J Med Genet 36: 494-496, 1999.

97.De Coppi P, Callegari A, Chiavegato A, et al: Amniotic fluid and bone marrow derived mesenchymal stem cells can be converted to smooth muscle cells in the cryo-injured rat bladder and prevent compensatory hypertrophy of surviving smooth muscle cells. J Urol 177: 369-376, 2007.

98.Perin L, Sedrakyan S, Giuliani S, et al: Protective effect of human amniotic fluid stem cells in an immunodeficient mouse model of acute tubular necrosis. PLoS One 5: e9357, 2010.

99. Moorefield EC, McKee EE, Solchaga L, Orlando G, Yoo JJ, Walker S, Furth ME and Bishop CE: Cloned, CD117 selected human amniotic fluid stem cells are capable of modulating the immune response. PLoS One 6: e26535, 2011.

100. Weber B, Emmert MY, Behr L, et al: Prenatally engineered autologous amniotic fluid stem cell-based heart valves in the fetal circulation. Biomaterials 33: 4031-4043, 2012.

101. Tian H, Bharadwaj S, Liu Y, Ma PX, Atala A and Zhang Y: Differentiation of human bone marrow mesenchymal stem cells into bladder cells: Potential for urological tissue engineering. Tissue Eng Part A 16: 1769-1779, 2010.

102. Fowler CJ, Griffiths D and de Groat WC: The neural control of micturition. Nat Rev Neurosci 9: 453-466, 2008.

103. Adamowicz J, Drewa T, Tworkiewicz J, Kloskowski T, Nowacki M and Pokrywczyńska M: Schwann cells - a new hope in tissue engineered urinary bladder innervation. A method of cell isolation. Cent European J Urol 64: 87-89, 2011.

104. Hindryckx A and De Catte L: Prenatal diagnosis of congenital renal and urinary tract malformations. Facts Views Vis Obgyn 3: 165-174, 2011.

105. Koh CJ and Atala A: Tissue engineering, stem cells, and cloning: Opportunities for regenerative medicine. J Am Soc Nephrol 15: 1113-1125, 2004.

106. Fuchs JR, Terada S, Ochoa ER, Vacanti JP and Fauza DO: Fetal tissue engineering: In utero tracheal augmentation in an ovine model. J Pediatr Surg 37: 1000-1006, 2002.

107. Fuchs JR, Hannouche D, Terada S, Vacanti JP and Fauza DO: Fetal tracheal augmentation with cartilage engineered from bone marrow-derived mesenchymal progenitor cells. J Pediatr Surg 38: 984-987, 2003. 